\title{
わが国集中治療室の現状調査 一松田班調査結果報告一
}

今中 雄一*1 林田 賢史*1 村上 玄樹*1 松田 晋哉*2

要約：ICU入室患者の治療成績を向上させるには，患者の重症度評価と予後に関するデータ 蓄積が必要不可欠である。そこで, 全国のICUの実態・治療等に関する松田班調査が 2006, 2007，2008年度に行われた。各年度の10月の1カ月間にICUに入室した患者を対象に, Acute Physiology and Chronic Health Evaluation II (APACHE II ) スコアを用いた重症度評 価と予後, 各施設の ICU 運用状況等を調査した。今回は 2007 年度の調査結果を検討した。ベッ ド数は 6 床が最も多く，中央值は 8 床であった。午前 10 時に専任の医師がいない施設が $21 \%$ あり，夜間にはさらに増加した。APACHE II スコアは $11 ， 12$ 点が最も多く，実死亡率は APACHE II スコアから予測される死亡率より低かった。今後は治療に関与する因子を特定し, わが国ICUの治療成績向上を目指す必要がある。そのためには，恒常的なデータ収集システ ムの構築が必須である。

Key words: (1) performance measurement, (2)ICU physician staffing, (3) Acute Physiology and Chronic Health Evaluation II (APACHE II) score

\section{序 論}

1950 年代のポリオ流行時に, 呼吸補助が必要な患者 を1カ所に集めて治療したことで生存率が上がり, こ れを契機に集中治療医学 (critical care medicine, CCM) は発展した。その後, CCMの進歩は目覚まし く, 重症患者の予後は改善している。最近, 患者を治 療する場所を提供するだけではなく, CCM専門医 (intensivist) が重症患者の治療に関わる程度が予後を 左右することがわかってきた。Intensivistが治療の中

この論文は今号のハイライトで取り上げています。

内野 滋彦. わが国の集中治療室は適正利用されているの か. 日集中医誌 2010; 17: 141-144.
心的役割を担う closed ICUと, 主治医が治療の中心的 役割を担う open ICUを比較すると, closed ICUの方 が生存率は良い1),2)。残念ながら, わが国でclosed ICUの治療成績が良いかどうかは不明である。この原 因として, わが国に基礎データがないことが挙げられ る。ICU入室患者の治療成績を検討するには, 患者の 重症度評価と予後に関するデー夕蓄積が必要不可欠で ある。2005年に行われた厚生労働省の「医療施設（静 態・動態) 調査」によると, 特定集中治療室として届け 出をしているのは 670 施設であり, 調査病院総数の 7.4\%がICUを有している3)。しかし, intensivistの治 療への関与はもとより, 患者数, 患者予後は把握され ていない。これらの基礎データなしには, ICUの存在

\footnotetext{
*西村 匡司 (徳島大学) : 委員長

多治見公高 (秋田大学)

竹田 晋浩 (日本医科大学)

小谷透 (東京女子医科大学)

鶴田 良介 (山口大学)

長谷川隆一 (公立陶生病院)

福岡 敏雄 (倉敷中央病院)

武澤純 (名古屋大学)

*1 京都大学大学院医学系研究科社会健康医学系専攻医療経済学分野 ( $\mathbf{T} 606-8501$ 京都府京都市左京区吉田近衛町)

*2 産業医科大学医学部公衆衛生学 ( ₹ 807-8555 福岡県北九州市八幡西区医生ヶ丘1-1)
}

受付日 2009 年 1 月 19 日 


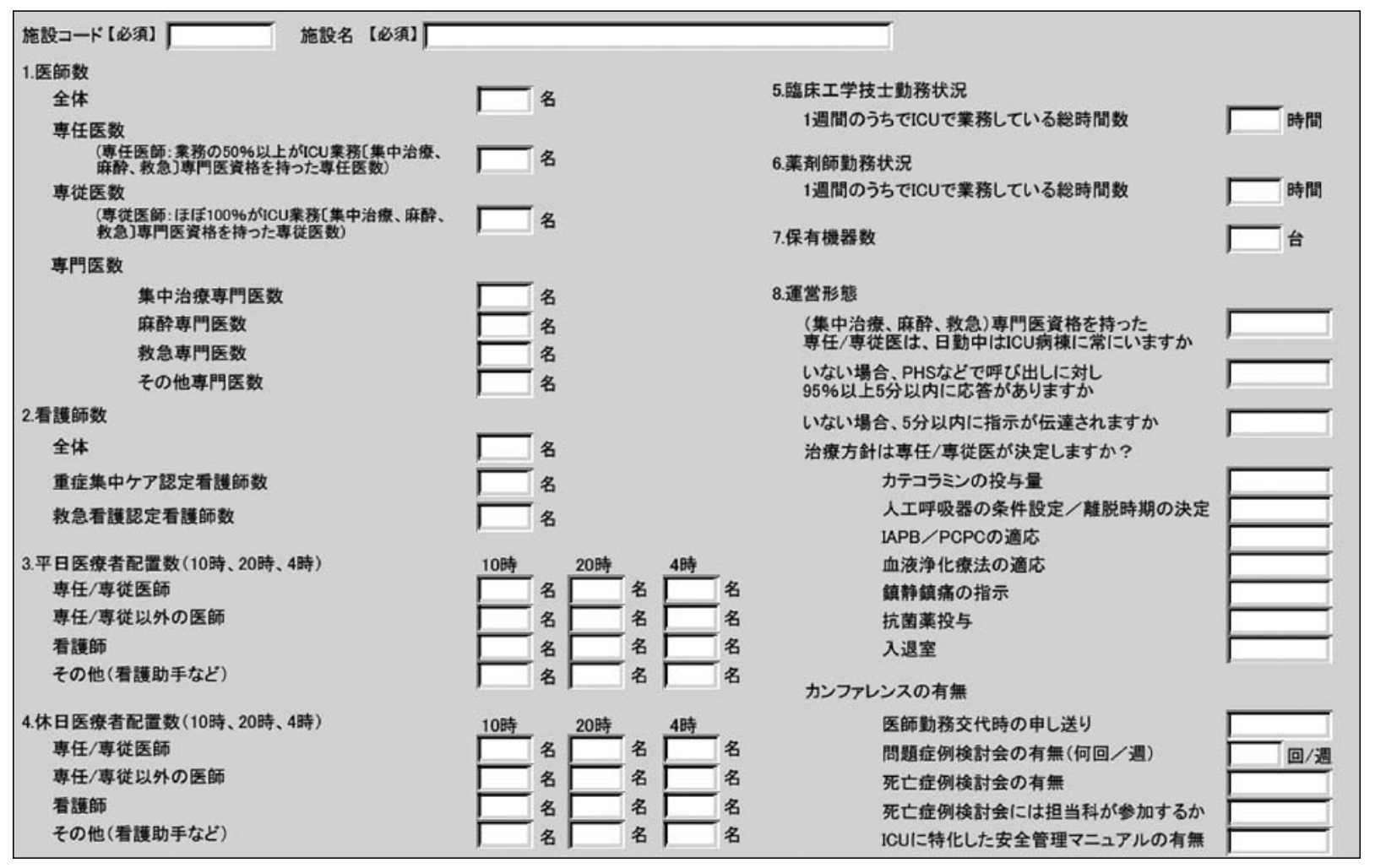

Fig. 1 Data format for each ICU

意義を確立することもできない。

そこで, 厚生労働省の政策科学推進研究事業として, 全国のICUの実態・治療等に関する松田班調査が 2006, 2007, 2008年度に行われた。各年度の10月の 1カ月間にICUに入室した患者を対象に, Acute Physiology and Chronic Health Evaluation II (APACHE II ) スコアを用いた重症度評価と予後, 各 施設のICU 運用状況等を調査した。2008年度の調査 結果は集計中であるが, 2006年度と 2007 年度の結果 は「診断群分類を活用した医療サービスのコスト推計 に関する研究報告 (H16-政策-027) 集中治療室・救急 医療および看護の業務量・機能評価等に関する研究」4) と,「包括払い方式が医療経済及び医療提供体制に及 ぼす影響に関する研究報告 (H19-政策-指定-001) 集 中治療室・救急医療の機能評価に関する研究」5)に報 告されている。2006年度の調査は初年度でもあった ことから, 特にAPACHE II スコアは不正確な可能性 が高かった。そのため, 2007 年度の調查前には APACHE II スコア入力上の注意点に関する説明会を 開催し, 正確なデー夕収集ができるように努めた。調 査結果の正確度が向上したと考えられるため, 本稿で は 2007 年度の調査結果を中心に報告する。

\section{方 法}

2007年 4 月時点で診断群分類 (diagnosis procedure combination, DPC) に参加している施設に調査協力依 頼を行った。本調査は, 「包括払い方式が医療経済及 び医療提供体制に及ぼす影響に関する研究」5)の一部 であり, 集中治療室に関しては松田班と日本集中治療 医学会 ICU 機能評価委員会が協力して行った。

調査対象は特定集中治療室加算を算定していること が条件であり, その他の制限はない。協力を表明した 施設に施設調査, 患者調査用のフォーマットを送った。 さらに, データ収集が正確に行われるよう, 参加協力 施設を対象に, 調査開始 2 力前に調査の意義, 方法, 調査項目について説明会を開催した。

調査項目は,「施設調查」と「患者調査」に分かれて いる。施設調査の項目を Fig. 1に示す。医師数につい ては専従医をどう定義するかが問題となったが,「ICU の業務にほぼ $100 \%$ 従事している医師」を専従医とし た。この $100 \%$ 従事とは勤務時間ではなく, 各医師の 業務全体の中でICU 業務に従事している割合を基準 にしたものである。また, 看護師数やその他のコメディ カルの人数, 保有機器数も調査した。日中や夜間の医 師・看護師数については 10 時, 20 時, 4 時にICUに勤 


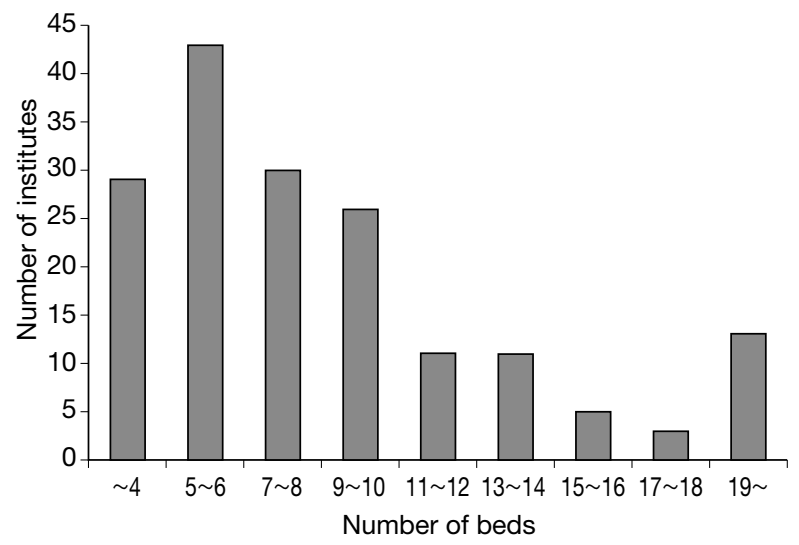

Fig. 2 Number of beds in each ICU

The ordinate axis shows the number of ICUs, and the abscissas axis shows the number of ICU beds in each ICU.

務している人数を調查した。これらの調查はある1日 の配置であり,1カ月を通じてのものではない。運営 形態については, closed と openの定義が不明暸であ るため, Leapfrogの定義 (専任/専従医が日勤中は ICU 病棟に常にいるか, いない場合, PHSなどでの呼 び出しに対し $95 \%$ 以上で5分以内に応答があるか，い ない場合, 5 分以内に指示が伝達されるか）を基に調查 項目を設定した。

患者調查の項目としては, 10 月の 1 月間にICUへ 入室した患者全員の APACHE II スコアを調査し, 患 者の予後は11月30日まで観察した。患者の重症度評 価と予後については, APACHE II スコアをはじめと するデータスクリーニングを行い, 転帰が記載されて いる症例を対象とした。

\section{結 果}

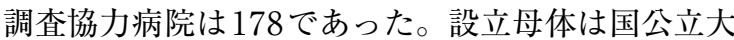
学附属病院 27 , 私立大学附属病院 26 , 一般病院 95 , 国 公立病院 30 であった。

\section{1) ベッド数}

ベッド数を Fig. 2 に示す。看護師：患者比 $1 ： 2$ を維 持する必要上, ベッド数が奇数である医療施設は少な いので,例えば5床と 6 床を一緒に集計した。平均は 9.8 床, 最も多いのは6床で, 中央值は 8 床であった。

\section{2) 医師数}

10 時, 20 時, 4 時にICU内にいた医師数を Fig. 3 に 示す。ICU内に医師がいなかったとした病院は, 10 時 が38 (21\%) あり，20時，4時ではそれぞれ58 (33\%)， $64(36 \%)$ と増加した。いずれの時間帯でも, 専任医 の数は 1 名が最も多かった。 1 人の専任医が担当する

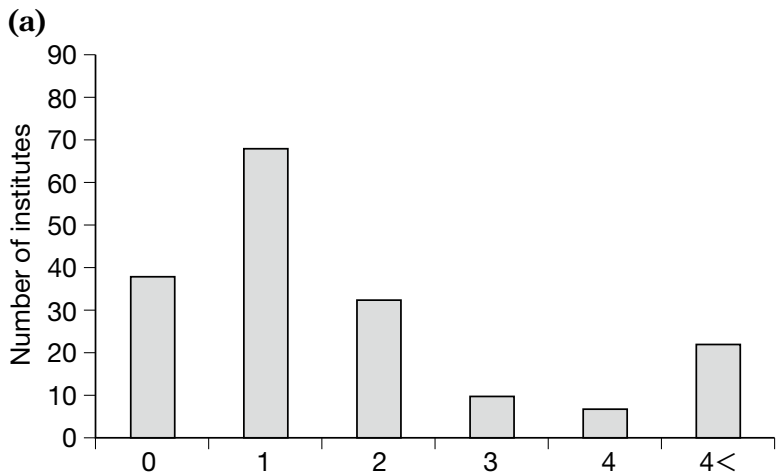

(b)

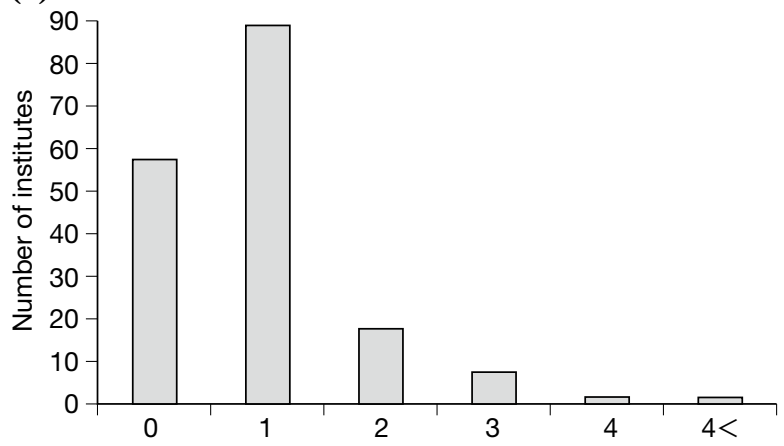

(c)

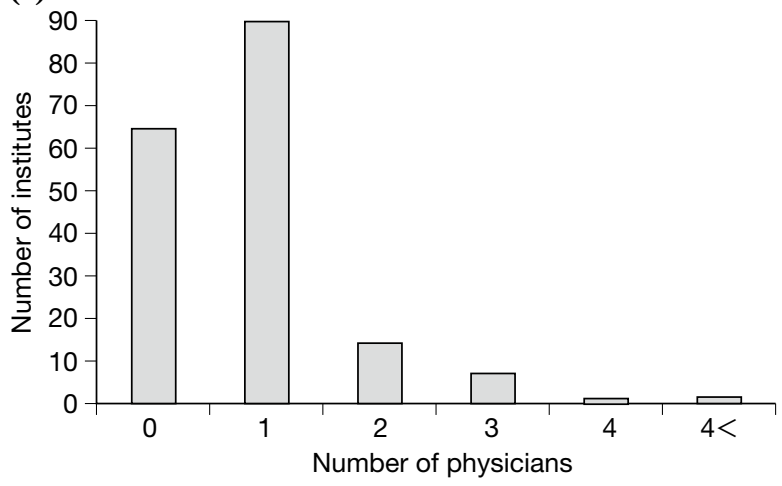

Fig. 3 Number of physicians working in the ICU (a) 10:00, (b) 20:00, (c) 4:00.

患者 (ベッド) 数は12名 (床) 超が多かった (Fig. 4)。

3）患者データ

(1) 年歯分布

2007 年 10 月にICUに入室した患者を対象とした年 齢分布を Fig. 5 に示す。患者数は10,163名で, 男女と もに同様な分布を示した。男女ともに50歳台後半か ら 60 歳にかけて患者数が増えていき, 高齢化社会を 反映して 70 歳台が最も多かった。

(2) APACHE II スコア

全患者の APACHE II スコア分布をFig. 6に示す。 11,12 点が最も多かった。患者毎の入力デー夕を検討 し, 病院転帰が明確な 4,922名のデー夕を詳しく分析 した。APACHE II スコアから予測される死亡率と実 際の死亡率を検討すると, スコアが高くなるにつれて 
日集中医誌 J Jpn Soc Intensive Care Med Vol. 17 No. 2

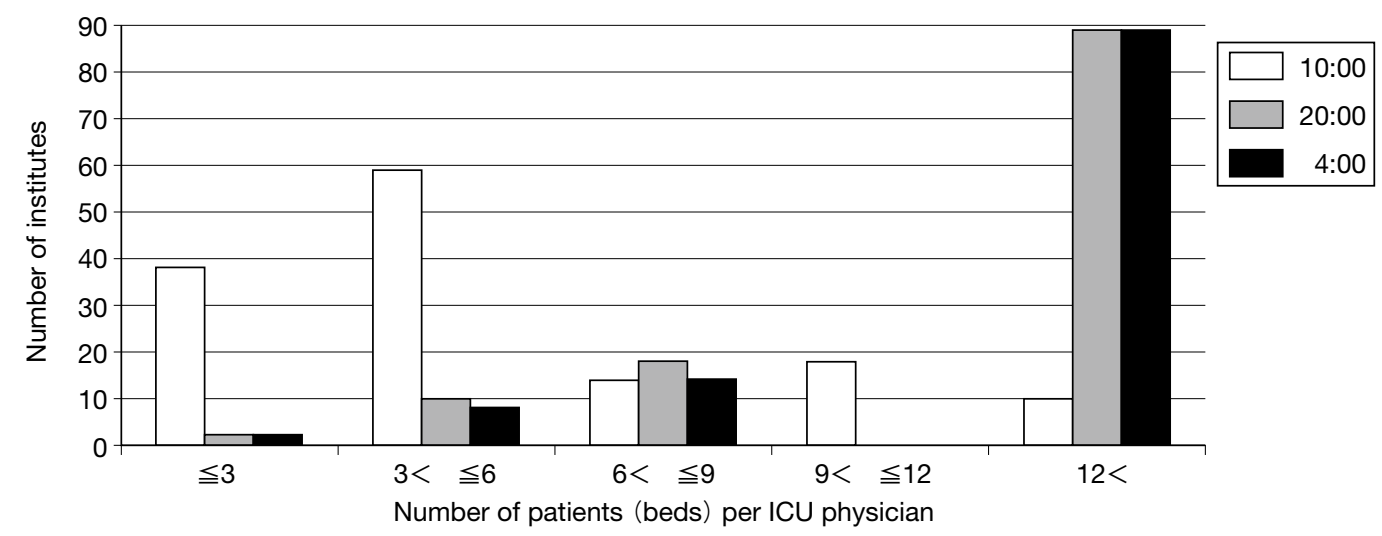

Fig. 4 Number of patients (beds) per ICU physician

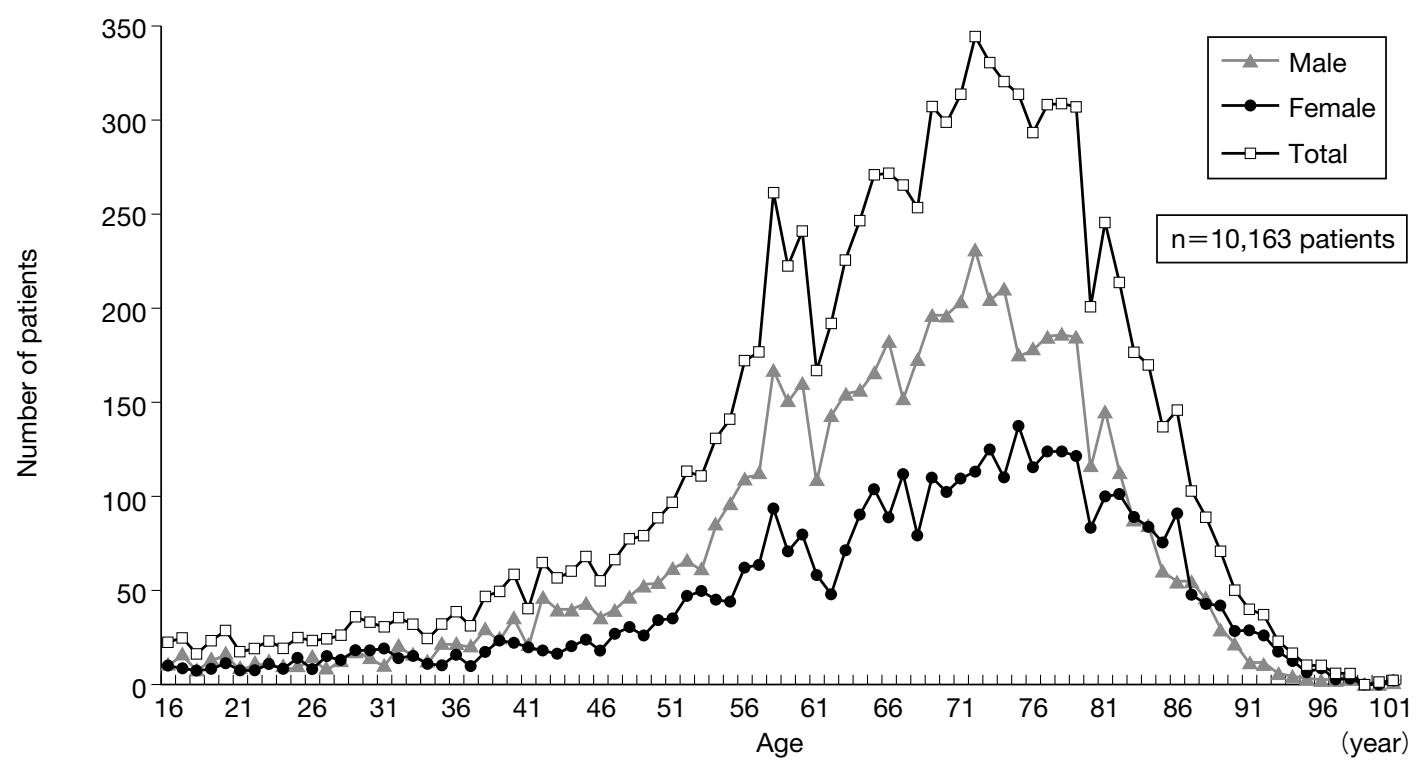

Fig. 5 Age distribution of all patients

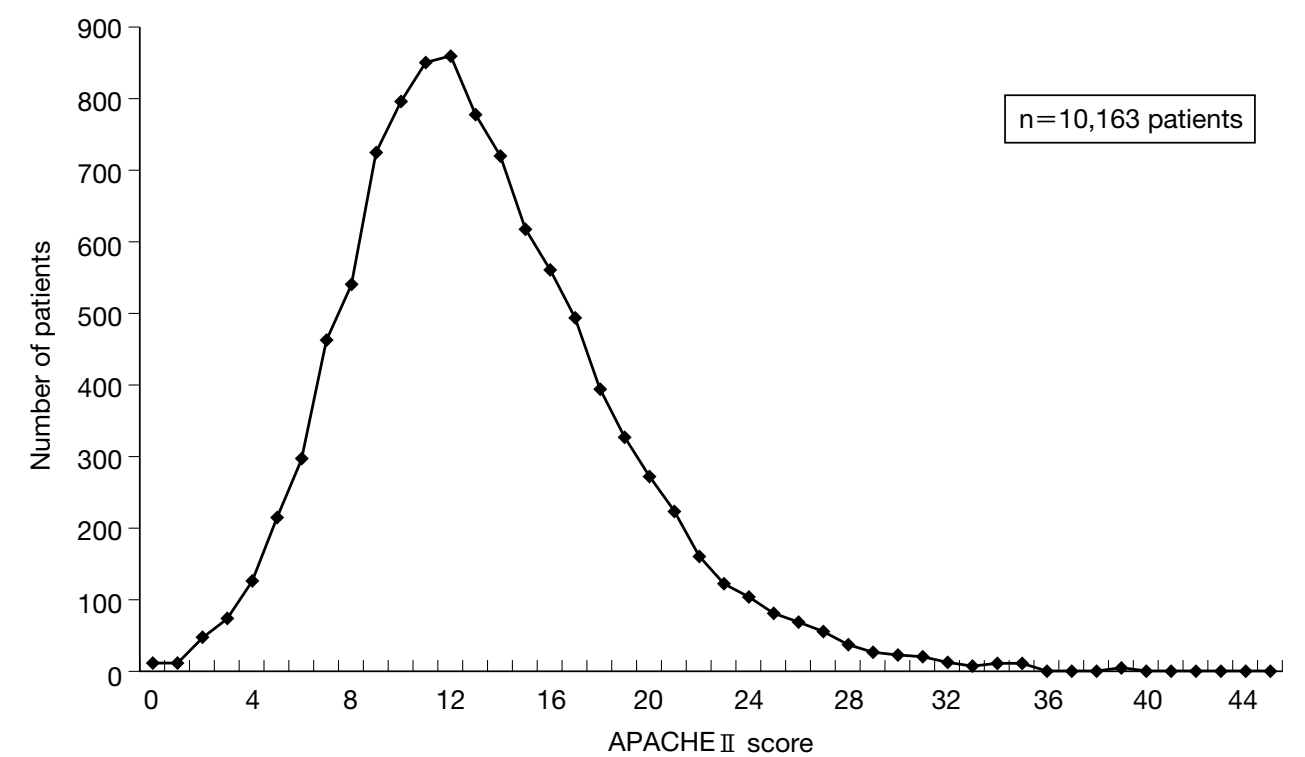

Fig. 6 Distribution of Acute Physiology and Chronic Health Evaluation II (APACHE II) scores 


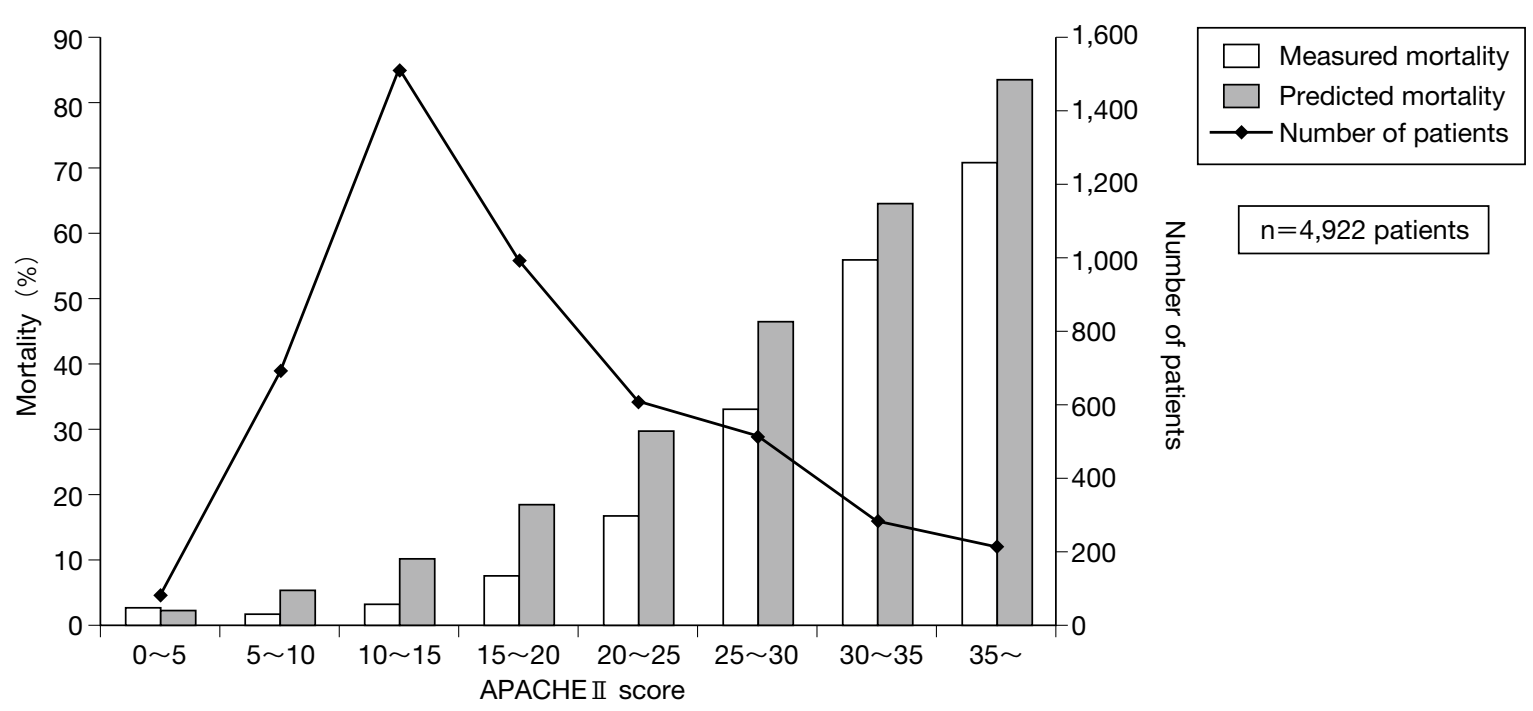

Fig. 7 Predicted and measured mortality APACHE II, Acute Physiology and Chronic Health Evaluation II.

死亡率は高くなり, スコアにかかわらず実死亡率が予 測死亡率より低かった (Fig. 7)。

\section{考察}

松田班による ICU 調査を基に，わが国のICUの現状 を分析した。本調査は, ICU患者の実態調査としては Sirio らの報告6)に次ぐ規模であるが, 大きな違いは調 査期間と参加施設数である。Sirioらは1987〜1989年 にかけて6施設を対象に調査を行っている。本調査は 1 月と短い期間であるが, 参加施設数は 178 と多い。 1 年を通じた調査ではないので, 得られたデータが参 加施設の患者像を代表しているかは不明である。しか し，多くの施設を調査していることより，わが国にお けるICUの全体像に近いと考えられる。

ベッド数の平均は 9.8 床であった。ICUベッド数が 50 床以上と報告した施設もあり, 特定集中治療室管理 料が算定されているベッド数が正しく報告されていな い可能性もある。平均值は高いが, 6 床が最も多く, 10 床以下の施設が $72 \%$ 占めた。各施設で病院全体 のベッド数の何％をICUベッドが占めているかは不 明である。

3 年に 1 度行われる厚生労働省の「医療施設（動態・ 静態) 調査」によると, 2005 年の特定集中治療室の病 床数は 1 施設当たり平均 8.1 床で, 6〜 7床の医療機関 数が 182 施設と最も多く, 今回の調査と同様な結果で あった。これ以外に, 特定集中治療室管理料を算定し ていない自称ICUが 1,186 施設ある。

北米とヨーロッパのICUを調査した報告を見ると， ICUベッド数は国により様々である7)。最も多い国で
は人口 10 万人当たり ICUベッドは 24 床であり, 最も 少ない国では3.3床である。わが国の現状はわからな いが, 4〜 5床と推測される。今後はICUベッドの必 要数が何床かを検討するための基礎データも必要で ある。

医師の配置を調査するため, 10 時, 20 時, 4 時に ICU内にいた医師数を質問したところ, 時間帯が遅く なるにつれて医師不在の施設数は増加していった。 ICUに医師がいるかどうかが患者予後に影響するかは 議論の残るところである ${ }^{8)}$ 。しかし, intensivistが常 にいて, 治療の中心となる closed ICUと, 主治医が治 療の中心となる open ICUでは治療成績が異なる 1),2)。 今回の調査では, 医師の配置と治療成績の関係を検討 することはできなかった。今後は, intensivistの配置 が治療成績に与える影響にまで踏み込んだ調查が必要 である。

今回はAPACHE II スコアを用いて重症度評価を 行ったが, スコアから見た死亡率は他の報告と大差は なかった。しかし, 本調査では疾患別のカテゴリ分類 が十分ではない。スコアが同じでも, カテゴリ分類が 患者予後に影響することはよく知られている。今後は, 他の報告と適切に比較できるような, より精度の高い データ収集が必要である。

\section{結 語}

わが国のICUの設置状況を見ると，施設により医師 の配置やベッド数に大きな差を認めた。日本集中治療 医学会がどのようなICUを理想と定めるかを提示し なければ, 学会としての機能を果たさなくなる危険性 
がある。今後は学会主導で実態調査を行い, 各施設に 治療成績向上のための改善策を指導できるような活動 を続けることが重要である。

平成 19 年度厚生労働科学研究費補助金 (政策科学推進研 究事業) 分担研究報告書 包括払い方式が医療経済及び医療 提供体制に及ぼす影響に関する研究 (H19-政策-指定-001) 集中治療室・救急医療の機能評価に関する研究.

主任研究者 :

松田晋哉 (産業医科大学医学部公衆衛生学 教授)

分担研究者：

今中雄一 (京都大学大学院医学研究科医療経済学分野教授)

研究協力者 :

林田賢史，村上玄樹 (京都大学大学院医学研究科医療経済 学分野)

西村匡司 (徳島大学大学院ヘルスバイオサイエンス研究部 集中治療医学 教授)

武澤 純 $($ 名古屋大学大学院医学系研究科救急・集中治療 医学 教授)

\section{文 献}

1) Pronovost PJ, Jenckes MW, Dorman T, et al. Organizational characteristics of intensive care units related to outcomes of abdominal aortic surgery. JAMA. 1999;281:1310-17.

2) Pronovost PJ, Angus DC, Dorman T, et al. Physician staffing patterns and clinical outcomes in critically ill patients. A systematic review. JAMA. 2002;288: 2151-62.

3) 厚生労働省大臣官房統計情報部．平成 17 年 (2005) 医療施 設 (静態・動態) 調査・病院報告の概況. Available from: http://www.mhlw.go.jp/toukei/saikin/hw/iryosd/05/ index.html

4) 今中雄一, 松田晋哉, 林田賢史, 他. 平成 18 年度厚生労 働科学研究費補助金 (政策科学推進研究事業) 分担研究報 告書『診断群分類を活用した医療サービスのコスト推計に 関する研究報告 (H16-政策-027)』集中治療室・救急医療 および看護の業務量・機能評価等に関する研究.

5) 今中雄一, 松田晋哉, 林田賢史, 他. 平成 19 年度厚生労 働科学研究費補助金 (政策科学推進研究事業) 分担研究報 告書 包括払い方式が医療経済及び医療提供体制に及ぼす 影響に関する研究報告 (H19-政策-指定-001) 集中治療室 · 救急医療の機能評価に関する研究.

6) Sirio CA, Tajimi K, Tase C, et al. An initial comparison of intensive care in Japan and the United States. Crit Care Med. 1992;20:1207-15.

7) Wunsch H, Angus DC, Harrison DA, et al. Variation in critical care services across North America and Western Europe. Crit Care Med. 2008;36:2787-93.

8) Levy MM, Rapoport J, Lemeshow S, et al. Association between critical care physician management and patient mortality in the intensive care unit. Ann Intern Med. 2008;148:801-9.

\section{Abstract}

\section{Physician staffing and patient outcome in Japanese ICUs}

Committee of Japanese ICU Evaluation, Japanese Society of Intensive Care Medicine Yuichi Imanaka*1, Kenshi Hayashida*1, Genki Murakami*1, Shinya Matsuda*2

\footnotetext{
${ }^{* 1}$ Department of Healthcare Economics and Quality Management, Graduate School of Medicine and Faculty of Medicine, Kyoto University

${ }^{* 2}$ Department of Preventive Medicine and Community Health, School of Medicine, University of Occupational and Environmental Health

${ }^{* 1}$ Yoshida Konoe-cho, Sakyou-ku, Kyoto, Kyoto 606-8501, Japan

*2 1-1 Iseigaoka, Yahatanishi-ku, Kitakyushu, Fukuoka 807-8555, Japan
}

The objective of this study was to investigate physician staffing and patient outcome in Japanese ICUs. ICU physician staffing, the Acute Physiology and Chronic Health Evaluation II (APACHE II) score, and patient outcome were prospectively collected from 178 ICUs in October 2007. Physicians were not present at 10:00 AM in 21\% of the ICUs, and this percentage increased to as much as $36 \%$ during the nighttime. The peak of the distribution of APACHE II scores was 11 to 12 . The measured mortality was lower than the predicted mortality based on the APACHE II score. ICU physician staffing varied significantly among the ICUs. To improve the quality of critical care in Japan, ongoing data collection is needed to determine the factors related to patient outcome.

Key words: (1) performance measurement, (2) ICU physician staffing, (3) Acute Physiology and Chronic Health Evaluation II (APACHE II) score 